\title{
Dean v. Lord Advocate and the Non-Refoulement Principle at the Margins
}

\section{Stephen Allen*}

(2016) 34 Chinese (Taiwan) Yearbook of International Law and Affairs (accepted unedited version, forthcoming, 2017)

\section{Introduction}

The case of Dean v. Lord Advocate concerned a request, made by the government of the Republic of China in Taiwan ("ROC"), for the extradition of a UK national to Taiwan in connection with serious criminal offences committed there, for which he was convicted and sentenced, by the ROC's municipal courts, in 2011 and 2012. The extradition request was made pursuant to an ad hoc Memorandum of Understanding ("MOU"), concluded between the ROC and UK governments in 2013, solely for this purpose (a bilateral treaty being out of the question as the UK government does not recognise the ROC as a de jure State or government). The MOU's conclusion attracted widespread attention in Taiwan because it was the first time that the ROC had entered into an extradition arrangement with a State. In its 2015 and 2016 judgments, the Scottish Appeal Court had to grapple with a number of difficult issues located at the margins of the legal regimes engaged by the case, namely, UK law, the European Convention for the Protection of Human Rights and Fundamental Freedoms ("ECHR") and general international law. ${ }^{1}$ The case's importance stems from the Appeal Court's answers to the following key questions. First, did Taiwan have sufficient legal personality to qualify as a "territory" for the purposes of the UK's Extradition Act 2003? Secondly, what was the status and effect of the $2013 \mathrm{MOU}$, and the diplomatic

\footnotetext{
* Dr Stephen Allen, BA, LLM, PhD, Barrister. Senior Lecturer, Department of Law, Queen Mary, University of London: s.r.allen@qmul.ac.uk. I would like to thank the Yearbook's anonymous reviewer for his/her comments and suggestions on the submitted version of this essay.

${ }^{1}$ (1950) 5 European Treaty Series. The first judgment of the Scottish Appeal Court in Dean v. Lord Advocate was delivered on 24 June 2015: [2015] HCJAC 52; [2015] SLT 419. The second judgment was delivered on 23 September 2016 [2016] HCJAC 83: [2016] SCL 84. References to particular paragraphs of the two judgments will be included in the text of this essay.
} 
assurances contained therein (and those given subsequently), as a matter of international law? Thirdly, and most significantly, what are the parameters of the ECHR's jurisprudence concerning the application of the non-refoulement principle ${ }^{2}$ when a non-Convention country seeks the extradition of an individual who is within a Contracting State's jurisdiction?

The absolute character of the prohibition on torture, inhuman and degrading treatment is well-entrenched. ${ }^{3}$ However, the existence of a severity threshold for the purpose of establishing proscribed behaviour has meant that, in practice, what qualifies as ill-treatment has acquired a circumstantial dimension, in certain respects. As a result, behaviour which may qualify as ill-treatment in one national (or regional) setting might be tolerated in another geographical situation for a range of structural, cultural and resource-based reasons. Different perspectives regarding the correct approach have led to a normative conflict between the absolute and relativist interpretations of the prohibition on ill-treatment. In these circumstances, this essay will harness the issues raised by Dean $v$ Lord Advocate to highlight the tensions that exist between national, regional and international legal regimes (and between law and politics more generally) in extradition cases which involve the application of the nonrefoulement principle and which engage the ECHR's provisions. In particular, it will examine the extent to which the government and courts of a Contracting State may be justified in imposing Convention standards on a non-Convention country. In addition, in recent years, MOUs have become increasingly popular for the purpose of concluding extradition arrangements and diplomatic assurances have become a

\footnotetext{
2 The non-refoulement principle holds that no State shall expel, return ("refouler") or extradite an individual to another State where there are substantial grounds for believing that he or she would at risk of being subjected to torture, inhuman, or degrading treatment. See section 3.1., below.

${ }^{3}$ Article 3 of the ECHR provides that: 'No one shall be subjected to torture or to inhuman or degrading treatment or punishment'.
} 
favoured means by which requested Contracting States have sought to protect the Convention rights of given individuals in extradition cases. However, both MOUs and diplomatic assurances are widely regarded as non-legal devices, as far as international law is concerned. The blurring of international law and politics with regard to the apparatus and operation of extradition has given rise to legitimate concerns about not only the manner in which the human rights of individuals who are subject to extradition requests are protected but also how the legal rights and obligations of States are maintained through the international legal order. It is suggested that the significance of these general concerns is illuminated in the present case due to the existence of persisting doubts about Taiwan's international legal status.

Against this background, the essay will examine the Appeal Court's first decision in Dean v. Lord Advocate ("the 2015 judgment") with a view to determining whether Taiwan qualified as a "territory" for the purposes of the application of $\S 194$ of the UK's Extradition. The essay will then focus on the Appeal Court's second decision in this case. The 2016 judgment was solely concerned with whether Dean's extradition to serve out his sentence in Taipei prison would put him in danger of suffering illtreatment, contrary to Article 3 of the ECHR. Accordingly, the third section will examine the relevant law concerning the principle of non-refoulement and its application in the context of the ECHR. In turn, it will scrutinise the arguments canvassed in the majority Opinions of Lady Paton and Lady Clark and the dissenting Opinion of Lord Drummond Young. The penultimate part will explore the case's wider importance for the development of the non-refoulement principle in cases involving non-ECHR countries; the practice of concluding MOUs and using diplomatic assurances in such situations; and for the ROC's international standing more generally. 


\section{The 2015 Appeal Court Judgment}

\subsection{Background and Applicable Law}

Zain Taj Dean, a British national, was involved in a road traffic accident in Taipei, Taiwan, on 25 March $2010 .{ }^{4}$ His car hit a motorcyclist who was killed as a result. The deceased was a young man who had been delivering newspapers. Dean was arrested and prosecuted in connection with this fatal accident. In March 2011, he was convicted, by the District Court of Taipei, of drink-driving, negligent manslaughter and leaving the scene of an accident. He was sentenced to two and a half years imprisonment. He appealed, unsuccessfully, against conviction and sentence to the High Court of Taiwan whereupon his sentence was increased to four years. He was granted conditional bail pending an appeal to the Supreme Court of Taiwan. But, in August 2012, Dean absconded while on bail. He fled to Scotland, using a friend's passport. The Supreme Court of Taiwan upheld his convictions and sentence, in absentia, on 20 December 2012.

In February 2013, the ROC's Ministry of Foreign Affairs contacted the UK government with a view to seeking Dean's extradition to Taiwan. On 9 October 2013, the Director-General of the Department of International Affairs in the ROC's Ministry of Justice issued a provisional arrest warrant. ${ }^{5}$ On 16 October 2013, a MOU was concluded between the ROC's Ministry of Justice and the UK government's Home Office concerning the arrangements for Dean's extradition to Taiwan. On 16 October 2013, the Edinburgh District Court issued a warrant for his arrest. Dean was subsequently arrested and kept in custody pending the resolution of this matter. On

\footnotetext{
${ }^{4}$ Dean was born on 10 January 1971. It has been reported that he had been living in Taiwan for some 19 years before the accident and that he was a business consultant. See 'British Citizen Goes on the Run with Fake Passport in Taiwan', The Telegraph, 30 January 2013. http://www.telegraph.co.uk/news/worldnews/asia/taiwan/9836278/British-citizen-goes-on-the-run-withfake-passport-in-Taiwan.html (last visited Jan. 16, 2017)

${ }^{5}$ As required by $\S 73$ and $\S 74$ of the Extradition Act 2003, c.41 (U.K).
} 
28 October 2013, the Director-General in the ROC's Ministry of Justice made a formal request to the Home Secretary regarding Dean's extradition. On 18 November 2013, the extradition request was certified by the Scottish Ministers. ${ }^{6}$ On 23 December 2013, the ROC's Director-General made certain undertakings regarding the time Dean had already served in a Scottish prison in connection with the offences in question; that the sentence would not be increased on his return to Taiwan; and that the death penalty would not be imposed. On 11 June 2014, the presiding Sheriff at the Edinburgh District Court ruled that Dean must be extradited to Taiwan. ${ }^{7}$ Following this decision, on 1 August 2014, the Scottish Ministers authorised Dean's extradition to Taiwan. Dean appealed against the judicial decision and the extradition decision made by the Scottish Ministers. ${ }^{8}$ The appeal was heard by the Appeal Court of the Scottish High Court of Justiciary and its judgment was delivered on 24 June 2015.

The international legal rights and obligations concerning extradition have evolved through the use of treaties, extradition being unknown to customary international law. ${ }^{9}$ The orthodox position is that, in the absence of a valid treaty, a State is not under a legal obligation to extradite an individual in response to an extradition request. ${ }^{10}$ However, $\S 194$ of the UK's Extradition Act 2003 provides for situations where no extradition treaty has been concluded between the requesting State and the requested State. In such cases, it allows for the making of ad hoc

\footnotetext{
${ }^{6} \S 70(1)$ of the Extradition Act provides: 'The Secretary of State must issue a certificate under this section if he receives a valid request for the extradition to a category 2 territory of a person who is in the United Kingdom'.

7 The ROC's Director-General provided further assurances regarding the extradition request, in a letter dated 25 July 2014, in which he undertook that Dean would not be prosecuted for any offences that were not included in the original extradition request, without the prior consent of the Home Secretary. Such undertakings were given in order to satisfy the 'speciality principle'. See Arthur Watts and Robert Jennings (eds) Oppenheim's International Law, Vol. 1, 961 (9th ed. OUP 1992). This principle is entrench in $\$ 129$ of the 2003 Act.

8 The appeal against the District Court's decision arose from $\$ 103$ of the 2003 Act while the appeal against the Scottish Ministers' decision was based on $\$ 108$ of the Act.

9 See Malcolm Shaw, International Law 498 (7th ed. CUP 2014).

${ }^{10}$ Anthony Aust, Handbook of International Law 246 (2nd ed. CUP 2010).
} 
arrangements for the purpose of extraditing a particular individual to a "territory". Specifically, § 194 applies:

(1) $[\ldots]$ if the Secretary of State believes that -

(a) arrangements have been made between the United Kingdom and another territory for the extradition of a person to the territory, and

(b) the territory is not a category 1 territory or a category 2 territory.

(2) The Secretary of State may certify that the conditions in paragraphs (a) and

(b) of subsection (1) are satisfied in relation to the extradition of the person.

(3) If the Secretary of State issues a certificate under subsection (2) this Act applies in respect of the person's extradition to the territory as if the territory were a category 2 territory.

(5) A certificate under subsection (2) in relation to a person is conclusive evidence that the conditions in paragraphs (a) and (b) of subsection (1) are satisfied in relation to the person's extradition.

\subsection{Was Taiwan a "Territory" for the Purposes of the 2003 Extradition Act?}

The ROC has not been recognised as a de jure State by any State. ${ }^{11}$ Today Taiwan is considered to be part of the People's Republic of China ('PRC") by nearly all States and International Organisations. ${ }^{12}$ In the aftermath of the Chinese civil war, the ROC was still widely regarded as being the legitimate government of the State of China. ${ }^{13}$

\footnotetext{
${ }^{11}$ See James Crawford, Brownlie's Principles of Public International Law 125 (8th ed. 2012).

12 The ROC is currently recognised as the de jure government of the State of China by 21 States (and the Holy See). The ROC operates informal representative offices, which perform a function similar to embassies, in many States.

${ }^{13}$ See the 1950 Memorandum to the Secretary-General regarding the Question of the Chinese Representation at the United Nations, UN Doc S/1466, 8 March 1950; Yuen-li Liang, Recognition by
} 
But, over time, individual States withdrew their recognition of the ROC in favour of the PRC government. ${ }^{14}$ Notwithstanding the unique dynamics of the cross-Taiwan Strait dispute, ${ }^{15}$ the ROC has maintained a credible level of autonomy. It has been characterised as a political entity under the authority of a de facto government, which effectively controls its territory, population and discharges the usual functions of government, including the capacity to conduct international relations. ${ }^{16}$ As a result, the ROC in Taiwan is often viewed as a sui generis territorialized political entity and this has fuelled doubts about the extent to which it enjoys a distinct personality as a matter of international law. ${ }^{17}$

The ongoing uncertainty regarding Taiwan's international legal status quickly became one of the principal issues in Dean v. Lord Advocate. Specifically, the

\footnotetext{
the United Nations of the Representation of a Member State: Criteria and Procedure 45 AM J INT'L L, 689 (1951); Myres McDougal and Richard Goodman, Chinese Participation in the United Nations 60 AM J INT'L L 671 (1966); and F B Schick, The Question of China at the United Nations 12 INT'L \& COMP. L.Q. 1235 (1963).

14 In 1971, the UN General Assembly resolved to seat the PRC government as the sole representative of the China. See General Assembly Resolution 2758(XXVI)(1971). 11 I.L.M. 561 (1972). Significantly, in 1979, the United States, formally recognised the PRC to be the sole de jure government of China and that Taiwan is part of China. The US-PRC Joint Communiqué provided: "The United States of America recognizes the Government of the People's Republic of China as the sole legal government of China [...] The Government of the United States of America acknowledges the Chinese position that there is but one China and Taiwan is part of China." Joint Communiqué of the United States and the PRC government, 73 AM J INT'L L 277 (1979).

${ }^{15}$ In 1991, the ROC retracted its territorial claim to the Chinese Mainland and it began to promote an ambiguous construction of "One China", by which it proclaimed the goal of reunification to be a long term aspiration. See the ROC's White Paper on "Relations Across the Taiwan Straits" (1994). See http://www.mac.gov.tw/ct.asp?xltem $=68295 \& C t N o d e=5836 \& m p=4$ (last visited Jan. 16, 2017). See the PRC's White Paper, "The Taiwan Question and the Reunification of China", The Taiwan Affairs Office (1993): http://china.org.cn/e-white/taiwan/index.htm_(last visited Jan. 16 2017); and the PRC's Second White Paper (2000): "The One-China Principle and the Taiwan Issue": www.china.org.cn/english/taiwan/7956.htm (last visited Jan 16 2017).

16 Hungdah Chiu, International Legal Status of the ROC 5 Contemporary Asian Studies Series 110 (1992). See Jean-Marie Henckaerts (ed), The International Legal Status of Taiwan in the New World Order: Legal and Political Considerations (Kluwer Law International, 1996); Jonathan I Charney, \& J R V Prescott, Resolving Cross-Strait Relations between China and Taiwan 94453 AM J INT'L L (2000) . See Stephen Allen, Statehood, Self-determination and the 'Taiwan Question 9 Asian Yearbook of International Law 191 (2000); Andrew Serdy, Bringing Taiwan into the International Fisheries Fold: The Legal Personality of a Fishing Entity 75183 British Yearbook of International Law (2006); and Stefan Talmon, The Recognition of the Chinese Government and the Convention on International Civil Aviation 8 Chinese Journal of International Law 135 (2009).

17 See James Crawford, The Creation of States in International Law (2nd ed. OUP 2006), 198-221; James Crawford, Chance, Order, Change: The Course of International Law (The Hague Academy 2014), 198; and Brad R Roth, Governmental Illegitimacy in International Law (OUP 1999), 263.
} 
Appellant contended that the Edinburgh District Court had made errors of law and fact in holding that Taiwan constitutes a "territory" in connection with the application of $\S$ 194 of the 2003 Act. Dean argued that the Secretary of State did not have the power to make special arrangements for his extradition there $(2015,14)$. In addition, the Appellant argued that, in reaching such a decision, the District Court was wrong because the basis for the Sheriff's conclusion that Taiwan was a territory did not fall within the bounds of judicial knowledge. To this end, the Appellant referred to a range of facts which, he submitted, showed that Taiwan should not be treated as a territory for the present purpose - including the protracted dispute between the PRC and the ROC; the fact that Taiwan was not a member of the United Nations and that the UK government did not recognise the ROC as a State $(2015,15)$. The Appeal Court noted that this argument had previously been rejected by the District Court. The Sheriff had observed that the term "territory" was defined nowhere in the 2003 Act. He had taken the view that this lack of definition was deliberate so as to ensure the scope of the Act was not curtailed by the matters of pure nomenclature $(2015,14)$. Further, he decided that the term could be said to encompass nations, political entities and States as long as they conformed to: "a recognisable legal jurisdiction in a viable and settled area of populated land with a level of judicial authority stable and organised enough to be recognised and accepted by the United Kingdom" $(2015,14)$. On the facts, the Sheriff concluded that Taiwan could satisfy the test for a "territory".

The Appeal Court agreed that Taiwan constituted a "territory" for the purposes of the 2003 Act and that, in accordance with §194(5), the Secretary of State's certification that Taiwan was a territory for this purpose was conclusive of such a status $(2015,16)$. Lady Paton, giving judgment on behalf of the Court, said: 
"The critical question is whether Taiwan is a "territory" for the purposes of the Act $[\ldots]$ The essential features of a "territory" are in our opinion threefold: there must be an area of land; that land must contain some population; and the land and population must be subject to effective government, including a functioning legal system" $(2015,17)$.

Moreover, the Appeal Court decided that the Sheriff was entitled to make the findings of fact, which underpinned his decision, as they fell within the scope of judicial knowledge $(2015,18) \cdot{ }^{18}$ Lady Paton stated that the Sheriff's findings of fact could be supported by a "cursory examination" of relevant sources. In response to the Appellant's arguments about the effects of the dispute between the PRC and ROC and the controversial status of Taiwan within the international community, she observed that:

"Many countries around the world have disputes with neighbours over the precise location of their boundaries, and the existence of such dispute could not possibly have the result that a country could not be considered a "territory". The sheriff further held that Taiwan has good international relationships, a flourishing export market and an internationally accepted democracy. None of these, however, is essential for the existence of a territory; apart from land and population, effective government is all that is required. Finally, the sheriff held that there were historic and long-standing political difficulties with the People's Republic of China, which had taken the seat in the United Nations previously

\footnotetext{
18 In McTear v. Imperial Tobacco Ltd, [2005] 2 SC 1, Lord Nimmo Smith defined judicial knowledge as: "The judge will take notice of the matters... which can be immediately ascertained from sources of indisputable accuracy, which are so notorious as to be indisputable..."; quoted in Dean v Lord Advocate (2015 judgment), supra note 1, [17].
} 
occupied by Taiwan. [...] Indeed, matters go further: the People's Republic of China denies the right of Taiwan to exist as an independent state. Nevertheless these factors are, in our opinion, irrelevant to the question of whether it is a "territory" for the purposes of the 2003 Act; while effective government is essential, it does not matter whether that government is recognised by others, or even whether its right to govern is denied by others $[\ldots] "(2015,19)$.

In Dean v. Lord Advocate, the courts were not required to address, directly, the question of Taiwan's international legal status but it is interesting to note how the test for qualifying as a "territory", devised by the District Court and the Appeal Court for the purposes of the application of the Extradition Act 2003, closely resembled the classical test for statehood in international law. At this point it is important to recall that statehood is a claim of right and the fact that the ROC does not maintain such a claim should be viewed as being determinative of its international legal status. ${ }^{19}$ Nevertheless, as numerous municipal law cases show, this state of affairs does not prevent the ROC from having legal personality for certain purposes. ${ }^{20}$

The starting point for determining whether a putative entity qualifies as a State for the purposes of international law is generally considered to be the criteria enumerated in the 1933 Montevideo Convention on the Rights and Duties of States: Article 1 provides that the State as a person of international law should possess the following criteria: (a) a permanent population; (b) a defined territory; (c) government;

\footnotetext{
${ }^{19}$ See Daniel P O'Connell, The Status of Formosa and the Chinese Recognition Problem 50 AM J INT'L L 405, 415 (1956); and Crawford, The Creation of States in International Law, supra note 17, 211. But see Chiu, supra note 16, 11-14. For a more radical perspective see Lung Chu Chen, The US-TaiwanChina Relationship in International Law and Policy (OUP 2016).

20 See below.
} 
and (d) the capacity to enter into relations with other states. ${ }^{21}$ However, Talmon claims that classical international law offered a narrower test for statehood, namely, that, "a State exists if a population, on a certain territory, is organised under an effective public authority". ${ }^{22}$ To this end, he argues that the criterion regarding the capacity to enter into international relations is superfluous because non-recognised States are denied the opportunities that flow from the establishment of optimal relations with third States precisely because they are not recognised rather than due to a lack of capacity per se. ${ }^{23}$ Further, Talmon suggests that States accept that a non-recognised State (or government) may exercise factual control over its territory; consequently, the municipal courts of third States are prepared to accept that non-recognised States and governments possess legal personality, for certain purposes, in the context of municipal litigation because such regimes do, in fact, carry out executive, legislative and adjudicative functions, within their own municipal legal systems. ${ }^{24}$ In other words, the courts of third States accept that de facto governments, or entities, exercise jurisdiction within the territory they control for systemic purposes. ${ }^{25}$

Against this background, the test for a "territory" developed by the Sheriff, in the District Court in Dean v. Lord Advocate, clearly reflects the essential requirements for statehood. The Sheriff emphasized the need for a "viable and settled area of populated land" with an organised and stable public (judicial) authority that constitutes a recognisable legal jurisdiction. Moreover, he expressly referred to the need for such a "territory" to be, in fact, eligible for recognition by the UK government notwithstanding

${ }^{21}$ The Montevideo Convention on the Rights and Duties of States 28 AM J INT'L L Supp. 75 (1933), (1934). These elements have since acquired the status of general customary international law.

${ }^{22}$ See Stefan Talmon, The Constitutive Versus the Declaratory Theory of Recognition: Tertium Non Datur? 75 British Yearbook of International Law 101, 110 (2005).

${ }^{23}$ Id. 116-7.

24 Id. 147.

25 Id. This is apparent from the way that the European Court of Human Rights treated the Turkish Republic of Northern Cyprus's legal system in Loizidou v. Turkey (Merits) (1995) 20 EHRR 99 and Cyprus v. Turkey (2001) 35 EHRR 30. 
the possibility that the government may choose not to recognise it. Accordingly, while the Sheriff did not use the language of statehood explicitly he did use the terminology of recognition, which may be indicative of a close relationship between the recognition of a territory for the purposes of the application of the 2003 Act and the acceptance of the existence of a de facto government or entity - and, specifically, the validity of its municipal legal system by a national court of a (non-recognising) State pursuant to the resolution of a domestic legal dispute. The Appeal Court's approach to this issue virtually mirrored the test for classical statehood in international law without directly alluding to it. Moreover, it ruled that the UK's recognition policy towards the entity in question was irrelevant to the task of determining whether it qualified as a territory for the purposes of the 2003 Act. It does not follow from these rulings that the UK courts accept that the ROC qualifies as a State simply because the applicable test for a territory under the UK's domestic legislation broadly corresponds to the test for statehood at the level of international law. However, they do show that the UK courts are prepared to accept the validity of Taiwan's municipal legal system for purposes of the adjudication of municipal legal disputes.

The conclusion, reached in Dean v. Lord Advocate, that Taiwan qualifies as a "territory" for the purposes of the application of the UK's Extradition Act is consistent with previous decisions reached by the municipal courts of (non-recognising) States which acknowledge that the ROC possesses sufficient legal personality for the resolution of municipal law disputes within the forum State, notwithstanding persisting doubts concerning its international legal status. For instance, in the US AttorneyGeneral v Cheng Fu Sheng et al (1960), ${ }^{26}$ a case decided prior to the US government's decision to withdraw its recognition of the ROC government, the Court of Appeal of

${ }^{26}$ Court of Appeal, District of Columbia, 6 October 1959, 31 I.L.R. 349. 
the District of Columbia held that: "Since Formosa [Taiwan] was a geographical, social, and political entity, subject to the undisputed control of a Government, it was a "country" within the meaning and for the purposes of the [the US Immigration and Nationality Act 1952]". ${ }^{27}$ Further, it observed that while the term "country" was not defined in the Act it had to be given its ordinary meaning in a manner that was consistent with the purposes of the legislation. In Reel v Holder (1982), the English Court of Appeal had to decide whether the International Amateur Athletics Federation had the authority to expel Taiwan's athletics federation from the Organisation. ${ }^{28}$ It held that: "The term "country" referred to a territory within which a particular association controlled athletics. It was not synonymous with the term "State". A colony or non-selfgoverning territory was a 'country' for these purposes and so was Taiwan". ${ }^{29}$

More recently, in Civil Aeronautics Administration v Singapore Airlines Ltd, the Singapore Court of Appeal concluded that Taiwan could not qualify as a State for the purpose of pleading a defence of State immunity in response to a civil claim against the ROC's civil aviation authority. ${ }^{30}$ Despite the existence of extensive dealings and close co-operation between the governments of Singapore and Taiwan and the conclusion of numerous agreements and MOUs, the Appeal Court concluded that the government of Singapore had consistently adhered to the notion of "One China". Moreover, it observed that the evidence indicated that Singapore has always evinced an intention not to recognise Taiwan as a State. ${ }^{31}$ The Appeal Court concluded that Taiwan was not a State for the purpose of a claim of State immunity in the Singapore

\footnotetext{
27 Id. 350.

28 Reel v Holder (1981) 74 I.L.R. 105.

29 Id. 106.

30 (2004) 133 I.L.R. 371.

31 Id. [35-36].
} 
courts b.ecause it was not recognised as a de jure (or de facto) State by Singapore. ${ }^{32}$ Nonetheless, the Court acknowledged that the ROC possessed legal personality for the purpose of defending civil claims in Singapore's courts. To this end, the Court noted that: "... once it is appreciated that the non-recognition of Taiwan is only in respect of the Act there is no reason why its effect should or need be extended to other respects. That would be completely unwarranted. The existence of Taiwan is a fact and the government of Taiwan exercises control over a specified area". ${ }^{33}$

The issue considered by the Appeal Court in Dean $v$ Lord Advocate was whether Taiwan qualified as a "territory" for the purposes of the application of UK law rather than the question of whether Taiwan is a State as a matter of international law. Nevertheless, it is submitted that such an enquiry required the Court to undertake some kind of assessment of Taiwan's (international) legal personality for the purpose of establishing that it qualified as a territory in any event. At a general level, beyond the colonial context, modern international law is unfamiliar with the concept of a "territory". ${ }^{34}$ Accordingly, in order to devise a working conception of a territorialized political entity - whether consciously or otherwise - the obvious reference point is the well-established notion of statehood. Consequently, while the Appeal Court did not allude, directly, to the test of statehood at any point in its 2015 judgment, it is

\footnotetext{
32 The Singapore Court of Appeal decided that the Singapore government's refusal to say that Taiwan was a State meant that the absence of an Executive Certificate confirming that the government recognised Taiwan as a State it could not qualify as a State for the purposes of the Singapore State Immunity Act. To this end, it ruled that the courts and the government had to speak with one voice on such matters. See id. [27 and 41]. In contrast, in Parent v. Singapore Airlines Ltd., (22 October 2003), a case instituted in the Canadian courts arising out of the same incident, the Superior Court of Quebec took a broader view. It decided that the approach of the Canadian government, which was materially the same as the one adopted by the government of Singapore on this issue, required the Quebec Court to investigate for itself whether Taiwan was indeed a State by reference to the evidence available to it. The case of Parent $v$. Singapore Airlines Ltd., is addressed in Civil Aeronautics Administration v. Singapore Airlines Ltd, id. [37-41].

${ }^{33}$ Id. [50].

34 The notions of "Non-Self-Governing Territories" and "Trust Territories" were developed in Articles 73 and 76 of the UN Charter, respectively, with a view to promoting decolonisation.
} 
suggested that the question of Taiwan's international personality suffused its reasoning throughout and its findings on this matter are important because they bolster the view adopted in previous decisions that the ROC does possess a degree of international legal personality despite its widespread lack of international recognition. Moreover, as extradition arrangements presuppose the existence of relations of mutual trust between governments (or autonomous political regimes). To this end, if the UK government viewed Taiwan as an international outcast that lacked any measure of legal personality then it would not have considered the prospect of entering into an extradition arrangement with the government of such a political entity. Clearly any finding that Taiwan qualifies as a "country" or a "territory" by a municipal court for the purposes of the application of national law does not mean that Taiwan should be recognised as a State, as a result. ${ }^{35}$ However, it does show that the municipal courts of (non-recognising) third States are prepared to accept that Taiwan possesses legal personality for certain public law purposes despite their Executive's refusal to recognise the ROC as a State or government.

\subsection{Dean's Claims under the ECHR}

$\S 87(1)$ of the Extradition Act provides that, if an extradition request relates to an individual who has been convicted in the requesting State, a UK court must decide whether the extradition would be compatible with his or her rights under the European Convention on Human Rights, pursuant to the application of the Human Rights Act 1998. If it decides that extradition would be incompatible with such rights then it is required to order his or her discharge, under §87(2) of the 2003 Act.

\footnotetext{
35 Crawford has suggested that Taiwan has acquired that status of a "proto-State". See James Crawford, Chance, Order, Change: The Course of International Law, supra note 17, 361.
} 
Dean claimed that his Convention right to a fair trial, under Article 6, was engaged by the decision to extradite him to Taiwan. ${ }^{36}$ Specifically, he claimed that media bias had provoked judicial bias against him. ${ }^{37}$ Dean also made allegations that judicial corruption was rife within the ROC's legal system and that it had affected his own case too. ${ }^{38}$ In Soering v. UK, the European Court of Human Rights ruled that: "an issue might exceptionally be raised under Article 6 by an extradition decision where the fugitive has suffered or risks suffering a flagrant denial of a fair trial in the requesting country".39 Further, giving the leading Opinion in the House of Lords decision in R (Ullah) v. Special Adjudicator, Lord Bingham observed that a "very strong case" would need to be made out in order to rely upon Article $6 .{ }^{40}$ In the circumstances, in the District Court in Dean v. Lord Advocate, the Sheriff concluded that:

\footnotetext{
${ }^{36}$ Article 6(1) of the ECHR provides: "In the determination of his civil rights and obligations or of any criminal charge against him, everyone is entitled to a fair and public hearing within a reasonable time by an independent and impartial tribunal established by law [...]"

${ }^{37}$ Dean complained that the media in Taiwan had portrayed him as a remorseless rich foreigner who had been treated leniently by Taiwan's criminal justice system. He claimed that the media coverage was xenophobic and, in particular, that media hostility stemmed from his Indian ethnicity. 2015 judgment, supra note 1, [30-31]. The Appellant did not claim that the judges involved in deciding his case were biased against him, as such. Instead he argued that they were afraid to enter a true verdict in his case as a consequence of the public resentment towards him, [26].

${ }^{38} \mathrm{Mr}$ Chen, the lawyer who represented Dean at his trial in Taiwan, gave evidence during the extradition proceedings at the Edinburgh District Court. He claimed that judicial corruption was rife in Taiwan. However, the Sheriff observed that Chen could not provide evidence of specific examples of such alleged corruption and he admitted that he had no personal experience of it. Accordingly, the Sheriff concluded that Chen amounted to an unreliable witness on this point. Id. [35]. The Sheriff reached the conclusion that:

"[Mr Dean] has been given some information since his own difficulties in this matter have arisen [...], and he has chosen to believe it and to conclude that it may, by some remote possibility, apply to his case. I am clear that I cannot find that such information as he has applies to this trial, and I have to find that he is grasping at straws in that connection and is doing a disservice to the Taiwanese justice system in putting forward an entirely unsubstantiated allegation about one or more or all of the judges in his case being corruptly influenced [...] [36]."

39 (1989) 11 EHRR 439, [113].

40 [2004] 2 AC 323, [24]. Further, in Othman v. UK, (2012) 55 EHRR 1, the Strasbourg Court held that threshold for a finding of a violation of Article $6 \mathrm{ECHR}$ was extremely high. What was needed was a breach of the principles, which underpin the right to a fair trial that had the effect of destroying the very essence of the right guaranteed by Article 6, [260].
} 
"The simple fact is that all of the evidence that I have heard at this hearing indicates that Mr Dean had a very full and fair trial process [...] I have heard nothing in this hearing that suggests that there was any level of unfairness at all in relation to the provision of evidence in Taiwan far less a level of information which would suggest a blatant denial of his rights under article 6 of ECHR' $(2015,34)$.

The Appeal Court decided to uphold the Sheriff's findings. Consequently, it dismissed Dean's claim that he had not received a fair trial because the Appellant could not adduce evidence that his trial had amounted to a flagrant instance of injustice (2015, 48).

Dean's other main claim was that prison conditions in Taiwan were such that, if he were returned there, he would be exposed to inhuman or degrading treatment, contrary to the terms of Article 3 of the ECHR. ${ }^{41}$ The applicable test, developed in Soering $v$. UK, provides that a Contracting State will incur responsibility under the Convention, where: "substantial grounds have been shown for believing that the person concerned, if extradited, faces a real risk of being subject to torture or to inhuman or degrading treatment". ${ }^{42}$ Consequently, the Appeal Court had to decide whether Dean was at risk of being ill-treated, if he were to be extradited to Taiwan. ${ }^{43}$ Notwithstanding the Sheriff's ruling that Dean's extradition would not lead to a breach of this provision, the Appeal Court chose to adjourn the proceedings in order to hear

\footnotetext{
${ }^{41}$ Article 3 of the ECHR provides that: "No one shall be subjected to torture or to inhuman or degrading treatment or punishment".

${ }^{42}$ Soering, supra note 39, [91].

${ }^{43}$ See Ahmed v. Austria (1997) 24 EHRR 278. See Ivor Stanbrook and Clive Stanbrook, Extradition Law and Practice (2nd ed. OUP 2000), 103-105.
} 
further argument about this issue, with a view to determining the ultimate fate of the appeal $(2015,73-75)$.

\section{The 2016 Appeal Court Judgment}

In its second judgment, ${ }^{44}$ the Appeal Court held, by a majority verdict, that the Appellant's extradition would violate the terms of Article 3 of the ECHR. Specifically, the majority concluded that the available evidence supported the existence of substantial grounds for believing that there would be a real risk of suffering illtreatment, if Dean were to be detained in Taipei prison. Further, the majority ruled that the diplomatic assurances, given by the ROC government in the $2013 \mathrm{MOU}$ (and subsequently) were not sufficient to remove the established risk. As a result, under the provisions of $\S 87$ of the Extradition Act 2003, the Court ordered Dean's discharge.

\subsection{The Principle of Non-Refoulement and Article 3 ECHR}

Article 3 of the ECHR does not refer explicitly to the non-refoulement principle. ${ }^{45}$ In sharp contrast, Article 3(1) of the UN Convention Against Torture provides that: "No State Party shall expel, return ("refouler") or extradite a person to another State where there are substantial grounds for believing that he would be in danger of being subjected to torture". ${ }^{46}$ However, in Soering $v$ UK, the Strasbourg Court indicated that the absence of an express endorsement of this cardinal principle in Article 3 of the ECHR was not problematic. ${ }^{47}$ The Court held that it would be incompatible with the

\footnotetext{
44 This hearing was held on 27-29 January, 18-19 May and 22 and 24 June 2016. Judgment was delivered on 23 September 2016.

${ }^{45}$ See Jacobs, White and Ovey, The European Convention on Human Rights (5 $5^{\text {th }}$ ed. OUP 2010), 167194.

46 The UN Convention Against Torture and Other Cruel, Inhuman or Degrading Treatment or Punishment (1984) 1465 UNTS 85. See Manfred Nowak and Elizabeth McArthur, The United Nations Convention Against Torture (OUP 2008), 126-228.

${ }^{47}$ Soering, supra note 39, [88].
} 
values underpinning the European Convention if a Contracting State were able to surrender a fugitive, knowingly, to a third State where there were substantial grounds for believing that s/he would be in danger of being ill-treated in the event of his or her extradition. ${ }^{48}$ Accordingly, it ruled that the non-refoulement principle could be implied into the terms of Article 3 of the ECHR. Moreover, as noted above, in Soering, the European Court established the applicable test in such situations, namely, that a Contracting State will incur responsibility under Article 3, where: "substantial grounds have been shown for believing that the person concerned, if extradited, faces a real risk of being subject to torture or to inhuman or degrading treatment". ${ }^{49}$

This test has been reiterated by the Strasbourg Court on numerous occasions since that time. In Saadi v. Italy, the Court stated that, in order to qualify as a real risk of ill-treatment, there must be more than a chance that the proscribed treatment will occur. ${ }^{50}$ It has been observed that this test will be satisfied by a risk that amounted to something less than the balance of probabilities. ${ }^{51}$ Nevertheless, it has been repeatedly stated that the requirement to engage in prospective assessments about what might happen in the event of a given individual being removed, returned, expelled or extradited does not affect the burden of proof in such cases, it remains with the Applicant. ${ }^{52}$ Moreover, while the prohibition on torture, inhuman and degrading treatment is absolute what qualifies as ill-treatment depends on the circumstances of a given case. Specifically, it has been shown that the terms of Article 3 will only be satisfied if a minimum level of severity of harm is established. ${ }^{53}$ In situations where a request has been made for the extradition of an individual from the jurisdiction of a

\footnotetext{
${ }^{48}$ Id.

49 Id. [91].

50 [2009] 49 EHHR 30, [128].

${ }^{51}$ Aldhouse v. Thailand [2012] EWHC 2235, [26].

52 Deya v. Kenya [2008] EWHC 2914 (Admin) [36-37].

${ }^{53}$ Elashmawy v. Court of Brescia, Italy [2015] EWHC 28 Admin, [49].
} 
Contracting State, and the receiving State is not a party to the ECHR, the courts of the requested State must conduct a rigorous assessment of the circumstances of the case under consideration. ${ }^{54}$ However, the Strasbourg Court has stated that, in order to grant extradition in such a case, a Contracting State is not under an obligation to impose Convention standards on a receiving State that is not a party to the ECHR. ${ }^{55}$

The existence of a gap between Contracting States and third States, as far as human rights protections are concerned, may be bridged by the use of diplomatic assurances in appropriate cases. However, the weight attached to undertakings, given by the receiving State, regarding the treatment of the person concerned in the event of his/her extradition, will depend on the quality of the assurances in question and the wider practices of the receiving State in connection with such matters. ${ }^{56}$ The practice of using diplomatic assurances has evolved to guard against violations of an individual's Convention rights in cases where the government of a Contracting State wants to extradite him or her to another State, notwithstanding evidence showing that his or her Convention rights are in danger of being violated, in the event of extradition. This practice has been justified as a pragmatic means of ensuring national security, preventing terrorism and facilitating justice. However, it has been strongly criticised on numerous grounds, including that such undertakings amount to unreliable or unenforceable promises that do not uphold the Convention rights of the affected individuals in reality. ${ }^{57}$ Despite these major criticisms, in Othman v UK, the Strasbourg Court, stated that its task was not to rule on the propriety, or wider significance, of the use of diplomatic assurances instead it was concerned with whether they had a

\footnotetext{
54 Chahal v. UK (1997) 23 EHRR 413, 96; and Saadi, supra, note 50, [128-9].

${ }^{55}$ Ahmad v. UK (2013) 56 EHRR 1, [177].

${ }^{56}$ Othman (supra, note 40), [189].

${ }^{57}$ Id. at 43-46. Also see Agiza v. Sweden (Comm. No. 233/2003), 20 May 2005 (UNCAT Committee); and Alzery v. Sweden (CPR/C/88/D/1416/2005), 10 November 2006 (Human Rights Committee).
} 
practical effect in particular cases. ${ }^{58}$ In order to determine the risk posed to the individual concerned the Court must, first, have regard to the general human rights situation in the receiving State before considering his or her particular circumstances. Ultimately, a court must satisfy itself that the diplomatic assurances provided by the receiving State are capable of alleviating an established risk of ill-treatment. ${ }^{59}$

In Othman, the European Court devised an extensive list of factors to assist national courts in assessing the reliability of specific undertakings in concrete cases. ${ }^{60}$ Given their importance to the present case, it is worth setting out the eleven Othman criteria in full:

1. Whether the terms of the diplomatic assurances have been disclosed to the Court;

2. Whether the diplomatic assurances are specific or general and vague;

3. The authority of the representative who has given the diplomatic assurances and whether they are capable of binding the receiving State;

4. If the diplomatic assurances have been made by the central government, whether the local authorities involved can be expected to observed them;

5. Whether the diplomatic assurances have been given in respect of treatment that is lawful and unlawful in the receiving State;

6. Whether the diplomatic assurances have been provided by a contracting state;

7. The length and the strength of the bilateral relation between the governments involved and the receiving State's record of abiding by similar assurances;

\footnotetext{
58 Othman, id. [186-7].

59 Chahal, supra note 54, [105], Saadi, supra note 50,, [148], and Othman, id. [187].

60 Othman, id. [189].
} 
8. Whether the receiving State's compliance with the diplomatic assurances can be monitored by diplomatic and/or other means;

9. Whether there is an effective system protecting against instances of ill treatments in the receiving State;

10. Whether the Applicant has previously been ill-treated in the receiving State; and 11. Whether the reliability of the diplomatic assurances in question has been examined by a municipal court of the sending Contracting State. ${ }^{61}$

In Othman, the Court observed that rarely will no weight at all be attributed to diplomatic undertakings given by a requesting State. ${ }^{62}$ It noted that as long as the assurances given are comprehensive, specific and cogent; the relations between the requested and requesting States are strong enough to give rise to mutual trust and confidence; the requesting State has a good record of honouring similar commitments in the past; and the reliability of the assurances has been rigorously assessed then it is open for a court to accept the diplomatic assurances in issue as amounting to a practical guarantee that the individual concerned will be protected against illtreatment. ${ }^{63}$ The conclusion may be reached even if powerful evidence exists to show that torture or ill-treatment is "widespread and routine" in the requesting State. ${ }^{64}$

The European Court has conceded that instances where the non-refoulement principle is engaged are often different from other kinds of ill-treatment cases because

\footnotetext{
${ }^{61}$ Id. [189].

62 Id. $[188]$.

63 Id. $[189]$.

$64 \mathrm{Id}$. [143-146] and [272]. It is worth reiterating that such a conclusion depends on a rigorous assessment the reliability of the diplomatic assurances in issue. For instance, in Chahal $v$. UK, the Strasbourg Court decided that the diplomatic assurances given by the Indian government were unreliable despite being given in good faith and the existence of relations of mutual trust and confidence between the two governments involved. It reached this conclusion due to evidence of the recalcitrant conduct of the regional security forces, which meant that the undertakings did not amount to a sufficient guarantee of individual's safety in the event of his return to the Punjab. See Chahal, supra note 54, [105].
} 
decision-makers are required to make assessments about the likelihood or foreseeability of harm. ${ }^{65}$ Consequently, fine-grained determinations may be made about whether a given individual should be extradited or not, leading to decisions about which different judges may disagree. ${ }^{66}$ As far as the extra-territorial dimension of Article 3 ECHR, occasioned via the application of the non-refoulement principle, is concerned, in Ahmad $v$ UK, the Strasbourg Court noted that: "treatment which might violate Article 3 because of an act or omission by a Contracting State might not attain the minimum level of severity which is required for there to be a violation of Article 3 in an expulsion or extradition case". ${ }^{67}$ In Ahmad, the Court made it clear that it is not for Contracting States to impose Convention standards on third States. ${ }^{68}$ Moreover, it noted that, in its jurisprudence, "it has been very cautious in finding that removal from the territory of a Contracting State would be contrary to Article 3' especially where the receiving State has, "a long history of respect of democracy, human rights, and the rule of law". ${ }^{69}$ However, the extent to which Convention standards should be followed in non-Contracting States was precisely the issue that fell to be decided in Dean v. Lord Advocate.

\subsection{The Majority and Dissenting Opinions}

In her Opinion, Lady Paton observed that the ROC authorities had originally intended that, upon return, Dean would serve his sentence in Taipei prison under the conditions afforded to the general prison population $(2016,48)$. However, she noted that concerns about the conditions of his detention, which came to light during the

\footnotetext{
${ }^{65}$ Ahmad, supra note 55, [178].

${ }^{66}$ Id. 178 and see $R$ (Wellington) v. Secretary of State for the Home Department [2008] UKHL 72.

${ }_{67}$ Ahmad, id. [177].

68 Id.

69 Id. $[179]$.
} 
proceedings, meant that they were no longer planning to follow such a course of action. She said, step by step, they had sought to devise special arrangements for him in an effort to comply with the requirements of Article $3(2016,48)$. The First Respondent's expert witness, Dr McManus, was engaged to investigate the prison conditions in which the Appellant would be detained ((2016, $30 \& 34)$. Nevertheless, from his impression of the general conditions in Taipei prison and the available data, Dr McManus took the view that the prison was grossly overcrowded and significantly understaffed at material time. Specifically, he noted that the prison regime failed to meet a number of relevant CPT Standards. ${ }^{70}$ Consequently, he was not prepared to say that, if the Appellant were to be subjected to general prison conditions, his treatment would comply with the terms of Article $3(2016,35)$.

According to Lady Paton, the key question was whether this exceptional regime, underpinned by a series of diplomatic assurances, was sufficient to remove the risk of ill-treatment in the event of Dean's extradition to Taiwan $(2016,45)$. She was troubled by the evidence of the general conditions affecting Taipei prison during the period in question, noting that overcrowding had reached $41 \%$ by the time of $\mathrm{Dr}$ McManus's visit in August 2015 (2016, 51). ${ }^{71}$ Lady Paton quoted from the CPT Standards regarding the consequences of gross overcrowding in prisons. They stated that:

\footnotetext{
70 Dean v Lord Advocate, 2016 judgment, supra note 1, [32-33].The Council of Europe Committee for the Prevention of Torture is the monitoring body for the European Convention on the Prevention of Torture (1987) ETS No. 126. It is responsible for developing standards designed to prevent instances of ill-treatment. CPT Standards (CPT/Inf/E (2002) 1-Rev. 2015): http://www.cpt.coe.int/en/about.htm (last visited Jan.16, 2017). The UK ratified the European Convention on the Prevention of Torture in 1988.

${ }^{71}$ Lady Paton referred to the statistical evidence which showed that each prison inmate had only 1.5 square metres of cell space, which was below the 2.31 square metres minimum specific by the ROC's prison authorities [33], and substantially below the 4 square metres recommended by the CPT Standards [32].
} 
"An overcrowded prison entails cramped and unhygienic accommodation; a constant lack of privacy (even when performing such basic tasks as using a sanitary facility); reduced out-of-cell activities, due to demand outstripping the staff and facilities available; overburdened health-care services; increased tension and hence more violence between prisoners and between prisoners and staff. This list is far from exhaustive. The CPT has been led to conclude on more than one occasion that the adverse effects of overcrowding have resulted in inhuman and degrading conditions of detention..."72

Accordingly, she decided that it was highly doubtful that they would be able to fulfil the assurances, given the degree which the prison was overcrowded and under-resourced $(2016,52)$.

Lady Paton was also disturbed by the conditions of solitary confinement that Dean would have to endure as a result of concerns about his safety, namely his vulnerability to attack by resentful prisoners. In this respect, she referred to the relevant CPT Standards which provided that:

"[Page 20] paragraph 56 ... Solitary confinement can, in certain circumstances, amount to inhuman and degrading treatment; [Page 29] paragraph 53... The CPT has always paid particular attention to prisoners undergoing solitary confinement, because it can have an extremely damaging effect on the mental, somatic and social health of those concerned; [Page 29] paragraph $54 \ldots$ The CPT understands the term 'solitary confinement' as meaning whenever a

722016 judgment, [51]. CPT Standards, [13]. 
prisoner is ordered to be held separately from other prisoners, for example ... for the protection of the prisoner concerned. $(2016,53) . "$

Further, Lady Paton referred to CPT Standards which recommended that prisoners should be offered a range of activities that were purposeful and, specifically, that prisoners should have the opportunity to spend at least eight hours a day out of their cells in order to engage in meaningful activities. ${ }^{73}$ Moreover, she thought that the medical services available in Taipei prison were inadequate. She noted that there were insufficient members of medical, paramedical and dental staff at the prison and she indicated that such a state of affairs was contrary to the relevant CPT Standards. ${ }^{74}$ Finally, Lady Paton drew attention to the expert evidence which indicated that there was no established means by which a prisoner could challenge the conditions of his or her detention through the municipal courts in Taiwan $(2016,57)$. In her view, this situation was also contrary to fundamental CPT standards $(2016,54)$.

In his dissenting Opinion, Lord Drummond Young accepted that the general conditions in Taipei prison were poor and that gross overcrowding could lead to a finding of ill-treatment $(2016,75)$. But he relied upon Dr McManus's conclusion that, despite the poor conditions in Taipei prison, the undertakings provided by the ROC authorities would ensure that the prison regime did not meet the severity threshold required for a breach of Article 3 and that the proposed cell itself was Article 3 compliant (2016, 34 \& 82). Lord Drummond Young considered that the decisive factor was whether the diplomatic assurances, given by the ROC in the $2013 \mathrm{MOU}$, and subsequently, eliminated the risk of ill-treatment in the event of Dean's extradition

\footnotetext{
${ }^{73}$ CPT Standards, p.7, cited in the 2016 judgment, [53].

${ }^{74}$ CPT Standards, p.39, id, [55].
} 
(2016, $75 \& 81)$. To this end, he examined the undertakings concerning the proposed arrangements for Dean's incarceration in Taipei prison. He referred to an undertaking, given by the ROC government on 25 February 2014, that: Dean would be housed in a prison cell with fewer inmates than would normally be allocated to a cell; the occupants of such a cell would be foreign prisoners with no record of violence; the prison authorities would screen prisoners who may come into contact with the Appellant; Dean would be separated from group activities, if necessary; and a clear communications procedure would be established for the purpose of making requests and complaints $(2016,10)$. Lord Drummond Young concluded that, in principle, these assurances were sufficient to ensure Dean's safety $(2016,77) .{ }^{75}$

Lord Drummond Young thought that the claim that Dean would be vulnerable to attack from other prisoners, as a result of the privileged detention arrangements that were being proposed for him and his proclaimed notoriety was exaggerated (2016, 97-98). Nevertheless, he considered the issue of whether the practice, followed in the ROC's prison system, of determining eligibility of parole by reference to work duties undertaken while a prison inmate in Taiwan had prejudicial effect on the Appellant (2016, 87). Lord Drummond Young concluded that this practice may indeed be disadvantageous to Dean as concerns about the possibility of him receiving unfavourable treatment from other prisoners may well prevent him from engaging in group activities, such as work. ${ }^{76}$ But while Lord Drummond Young appreciated that the non-availability of parole would constitute a disadvantage, in his view, it did not qualify as ill-treatment $(2016,87)$. Ultimately, he concluded that this potential outcome

\footnotetext{
75 To this end, he noted that, on 19 August 2015, the ROC's Ministry of Justice gave a further undertaking, that the Appellant would be housed in a cell that was Article 3 compliant. 2016 judgment, [10] and [78].

76 The ROC prison authorities would only take time served in a prison in Taiwan into account for the purpose of calculating eligibility for parole. Therefore, the time that Dean had served in a Scottish prison would not count for towards any entitlement for his early release. 2016 judgment, [87].
} 
was attributable to Dean's decision to flee the jurisdiction rather than a punishment that would be imposed upon him by the prison authorities $(2016,101-2)$. The second cause for concern arose from the claim that fears for Dean's personal safety would result in his de facto solitary confinement $(2016,88)$. However, Lord Drummond Young adopted the view that any decision taken by the Appellant to remain in his cell resulted from a choice on his part $(2016,101) .{ }^{77}$ Accordingly, as far as Lord Drummond Young was concerned, such confinement would not amount to a violation of Article $3 .{ }^{78}$

Lord Drummond Young applied the Othman criteria to the facts. He thought that the first criterion was easily satisfied as there had been full disclosure of the terms of the diplomatic assurances during the proceedings $(2016,92)$. With regard to the second criterion, he said that the undertakings concerning the proposed arrangements for Dean's detention in Taipei prison were detailed and specific in nature $(2016,92)$. He thought that the third and fourth criteria were satisfied, as the key assurances had been given by the Director-General of the ROC's Ministry of Justice, and they were capable of binding the ROC. Moreover, the evidence indicated that they would be implemented by the Taipei prison authorities (2016, 92-93). Further, Lord Drummond Young observed that the fifth criterion was clearly met because the assurances related to the way in which lawful custodial arrangements were organised in Taiwan (2016, 93). He acknowledged that the sixth criterion could not be satisfied as Taiwan is not a party to the ECHR $(2016,93)$. He conceded that the ties between the UK and the ROC in Taiwan were weak due to the absence of diplomatic relations. Nonetheless, he alluded to the fact that the UK operates a representative office in Taipei and he

\footnotetext{
77 Lord Drummond Young noted that the same kind of practice may occur in a Scottish prison due to concerns about a prisoner's safety under Article 2 of the ECHR (the right to life) and Article 5 (the right to personal security). Id. [107].

78 Nor did he consider that the level of accessible medical services in Taipei prison qualified as illtreatment. Id. [103].
} 
indicated that there was no reason to suppose that the ordinary consular protections would be afforded to the Appellant in the event of his extradition. Moreover, he indicated that the ROC's undertaking, of 25 December 2015, suggested that this remedial mechanism would be available in the event of a failure to implement the undertakings properly $(2016,93) .{ }^{79}$ Lord Drummond Young noted the Foreign Office's confirmation that it conducted consular visits to UK nationals detained in prisons in Taiwan went some way towards satisfying the eight criterion $(2016,93)$. While he noted that the ROC had "ratified" the International Covenants on Human Rights (2016, $90 \& 93),{ }^{80}$ he appreciated that the under-developed state of prisoner rights in Taiwan meant it could not be said with certainty that the ninth criterion had been met $(2016$, 94). Lord Drummond Young observed that the tenth criterion was inapplicable on the facts and the final criterion was being satisfied through the current proceedings (2016, 94). He concluded that a sufficient number of the Othman criteria were satisfied for the ROC's diplomatic assurances to be taken into account for the purpose of deciding whether Dean's extradition would violate his Convention rights under Article 3 (2016, 95).

Lady Paton's reading of the Othman criteria was somewhat different. She concluded that criteria six to nine were not satisfied $(2016,56)$. In addition, to her concerns about the under-developed condition of prisoner rights in the jurisdiction, she thought the absence of international monitoring of prison conditions in Taiwan of any external enforcement methods, via United Nations or relevant treaty bodies, to be

\footnotetext{
79 The ROC government promised that if British officials in Taipei raised concerns about an alleged breach of assurance the ROC authorities would ensure that, if a breach had occurred, it would be remedied. Id. [10] and [79].

80 Prior to its widespread de-recognition in favour of the PRC, the ROC government played a significant international role in the development of international human rights treaties. However, while it signed the International Covenant on Civil and Political Rights and the International Covenant on Economic, Social and Cultural Rights, they were never ratified. The International Covenants were adopted by UN G.A. res. 2200A (XXI) (1966), UN Doc. A/6316 (1966); I.C.C.P.R., 999 U.N.T.S. 171, entered into force March 23, 1976; I.E.S.C.R, 993 U.N.T.S. 3, entered into force January 23, 1976.
} 
deeply problematic $(2016,56)$. Further, in her view, the lack of diplomatic ties and the shortcomings in the general system of the diplomatic protection as a means of holding a receiving State to account in the event that diplomatic assurances were breached, and the lack of relevant expertise on the part of the British officials stationed in Taipei, meant that the monitoring processes proposed in Dean's case were not fit for purpose $(2016,56)$. Relying on the authority of Florea $v$ Romania, Lady Paton stated that systemic problems could provide the basis for a finding that substantial grounds exist in support of a belief that an individual would be exposed to a real risk of ill-treatment in the event extradition were capable of direct application to the present case (2016, 58). ${ }^{81}$ These factors led Lady Paton to the conclusion that the exceptional arrangements proposed in this case were not sufficient to remove the real risk of illtreatment contrary to Article $3(2016,50 \& 59)$.

In sharp contrast, Lord Drummond Young placed considerable weight on the authority of Ahmad $v$ UK and the relativist viewpoint, expressed in that decision (2016, 73). To this end, he relied upon the case of Richards $v$ Ghana where the High Court held that "very strong grounds" would be needed before a court would be prepared to conclude that bad prison conditions meant that the minimum severity threshold had been reached where the requesting State was not a party to the Convention. ${ }^{82}$ Lord Drummond Young concluded that the Appellant had failed to prove that Article 3 would be infringed if he were to be extradited to Taiwan. He expressed the view that the arguments against extradition were predominantly based on the standards that would be applicable within the jurisdiction of a State that is a party to the $\operatorname{ECHR}(2016,76)$. Lord Drummond Young thought the diplomatic assurances, provided by the ROC

\footnotetext{
${ }^{81}$ Florea v Judicial Authority, Romania [2015] 1 WLR 1953, [32].

82 [2013] EWHC 1254 Admin [57-58]. Dean v Lord Advocate, supra note 1, 2016 judgment, [74].
} 
government, represented a genuine attempt to satisfy the concerns raised by reference to those standards and that they could be relied upon to remove the risk that Dean would suffer ill-treatment on his return to Taiwan $(2016,107)$.

On 4 November 2016, the Lord Advocate made an application to the Court of Appeal seeking leave to appeal its decision to the UK Supreme Court. By a majority verdict, leave to appeal was refused (Lord Drummond Young dissenting). ${ }^{83}$ The majority (Lady Paton and Lady Clark) decided that the judgment of 23 September 2016 was a fact-based verdict and that, as the decision revealed no material errors of fact, an appeal to the Supreme Court was unfounded. ${ }^{84}$ Moreover, the majority ruled that the unique nature of the facts in Dean v. Lord Advocate meant that the case had very little precedential value. Accordingly, it held that an appeal to the Supreme Court would not justified as the case did not manifest an issue of general public importance. ${ }^{85}$ Lord Drummond Young strenuously disagreed with the majority's conclusions. He considered that both the status and application of the Othman criteria and the extent to which courts could rely on the enforcement of diplomatic undertakings, by consular representatives, were in need of further clarification. Further, he took the view that these matters were liable to arise again the future in extradition cases and that they, therefore, satisfied the general requirement that appeals to the Supreme Court had to give rise to an issue of general public importance. ${ }^{86}$

\section{Analysing the Appeal Court's Judgments in Dean v. Lord Advocate}

\subsection{The Application of ECHR Standards to Non-Convention Countries}

\footnotetext{
83 [2016] HCJAC 117.

84 Id. [13].

85 Id. [14].

86 Id. [21-26]. He also thought that the issues involving the application of Article 3 of the ECHR gave rise to points of law rather than matters of fact, [23].
} 
As noted above, in Ahmad, the Strasbourg Court made it plain that the ECHR does not require Contracting States to impose Convention standards on third States in extradition cases. Moreover, in that case, it observed that what would constitute a violation of Article 3, if it were to occur within the jurisdiction of a Contracting State, would not necessarily qualify as a breach in an extra-territorial setting. ${ }^{87}$ The Court went on to identify instances where individuals had been ill-treatment while being subject to prison conditions. This list included situations where the responsible authorities had deliberately set out to debase or humiliate the individual in question; where measures were imposed that had the effect of causing fear and anguish; and where the individual concerned had suffered intense distress or hardship beyond the unavoidable level of suffering occasioned by detention. ${ }^{88}$ As previously mentioned, the Court added that it had been very cautious in finding that extradition to a nonConvention State would breach the terms of Article 3. ${ }^{89}$

It is clear that the list of factors provided by the European Court was not intended to be exhaustive and while the cases cited all concerned instances of illtreatment when the Applicants were held in custody they were not necessarily cases involving the application of the non-refoulement principle. However, it is possible to interpret the enumerated cases as providing generic guidance as to the level of severity of harm that would be required to justify a finding that the terms of Article 3 had been breached in a concrete "extra-territorial" case. To this end, it is notable that the Court referred to the examples given as "factors". ${ }^{90}$ In Richards v. Ghana, the English High Court measured the factual components of that case against the relevant

\footnotetext{
${ }^{87}$ Ahmad, supra note 55, [177]. Also see Aleksanyan v. Russia (2011) 52 EHRR 18.

${ }^{88}$ Ahmad, id. [178].

89 Id. [179].

90 Id. $[178]$.
} 
factors provided in Ahmad. ${ }^{91}$ It observed that the case law revealed, 'the need for very strong grounds before a Court would be willing to conclude that the prison conditions in a non-Convention State attain the level of severity" required for a violation of Article 3. ${ }^{92}$ In Richards, the High Court concluded that the Applicant would have had to endure "severe" prison conditions that fell well below Convention standards in the event of his extradition to Ghana and his subsequent detention (if convicted). ${ }^{93}$ However, it held that such prison conditions did not meet the required minimum threshold of severity, on the facts. ${ }^{94}$

Moreover, in Florea v Romania, an extradition case where the Applicant alleged that he would suffer ill-treatment as a result of his detention in a grossly overcrowded Romanian prison, it is worth noting that rather than discharging the Applicant, the High Court chose to adjourn the proceedings so that enquiries could be made to establish if Romania, a Contracting State to the ECHR, would be prepared to offer diplomatic assurances that would eliminate the evident risk of a violation of Article 3 in the instant case. ${ }^{95}$ In Dean v. Lord Advocate, the majority harnessed the authority of Florea in support of the view that general institutional problems could support the existence of a real risk of ill-treatment. However, the approach adopted by the High Court in that case was to explore whether diplomatic undertakings could remove such a risk. Evidently, the High Court did not think that the general prison conditions in Romanian

\footnotetext{
${ }^{91}$ Richards, supra note 82, [46], [60-65]. In that case, the Applicant sought to challenge his extradition to face a charge of attempt murder by arguing that, if he were convicted, prison conditions would amount to ill-treatment, contrary to Article 3. The High Court relied on the authority of Harkins v. UK (App. No. 9446/07) decided on 17 January 2012. The case was joined with Ahmad.

92 Richards, id. [58].

${ }^{93}$ The Chief Magistrate established that the conditions in Ankaful prison were adverse. They included that each cell housed 10 inmates leaving each prison little room (less than one square meter per individual); the cell toilet was less than one meter from the nearest beds; there was a serious problem with mosquitos in the prison (but no nets were provided); there was a lack of educational and recreational facilities available to prisoners. Id. [40-41].

94 Id. [65].

95 Florea, supra note 81, [44].
} 
prisons would be a barrier to satisfying the terms of Article 3, if special arrangements could be made for the Applicant for the purpose of his extradition. Consequently, it appears that that Florea is a questionable authority for the proposition that general prison conditions outweigh special arrangements made for a given individual in extradition cases.

In the light of the above, it is hard to overlook Lord Drummond Young's observation that: "The concerns about the conditions of detention were based in large measure on the standards that would be required in a Scottish prison ..." (2016, at 76) and, thus, within the jurisdiction of a Contracting State rather than in a third State. In Dean v. Lord Advocate, the majority interpreted the relevant law as it would have been applied within the jurisdiction of a Contracting State whereas Lord Drummond Young, in the minority, was prioritized the extra-territorial dimension of the case. The present author would argue that, in keeping with the tenor of the reasoning embraced by the Strasbourg Court in Ahmad, it cannot be correct that a third State must comply with ECHR standards in respect of behaviour which occurs within its jurisdiction, at least at a general level. To hold otherwise would mean that the Contracting State whose jurisdiction was engaged in a given case would, in effect, be exercising public authority within the territory of a State that was not a party to the European Convention. ${ }^{96}$ Nevertheless, in cases where the non-refoulement principle is engaged, jurisdictional considerations must be tackled. Specifically, the courts of the requested State must determine the nature and extent of the danger posed to the individual concerned and whether that any such risk can be eliminated by reliable means. Consequently, any assessment about the risk of ill-treatment in extradition or expulsion cases must focus,

\footnotetext{
${ }^{96}$ Article 1 of the ECHR provides that: 'The High Contracting Parties shall secure to everyone within their jurisdiction the rights and freedoms defined in Section I of this Convention.' The Strasbourg Court declined to endorse an unqualified interpretation of the ECHR in extra-territorial situations. See Bankovic v. Belgium (2001) 44 EHRR SE5, [71]; and Al-Skeini v. UK (2011) 53 EHRR 18, [149].
} 
predominantly, on the Applicant's particular circumstances rather than on the general human rights situation in the requesting State. But while this approach is consistent with the reasoning adopted by the European Court in Othman, determinations are, evidently, difficult to make because the general human rights situation and the particular circumstances of a given individual are often closely intertwined, and this especially true on the facts of Dean v. Lord Advocate. It is suggested that the tension between the general and the particular in cases involving the non-refoulement principle may only be resolved if the responsible Contracting State undertakes a thorough investigation into how the requirements of Article 3 could be satisfied in the event of the Applicant's extradition to the requesting State. The extent to which the UK government sought to ensure that Dean's treatment would meet the rigorous requirements of Article 3, in the event of his extradition, will be examined in the next sub-section.

\subsection{The Lack Engagement by the UK Government}

One of the key aspects of the majority's position was the lack of information in the public domain about prison condition in Taiwan. Lady Paton addressed this issue by saying that: "It seems that little is known in the United Kingdom about the conditions in which prisoners are held in Taiwan, and in particular, in Taipei prison" $(2016,40)$. Consequently, she expressed the view that the evidential hearing in 2016 had been "something of a voyage of discovery" $(2016,60)$. In contrast, Lord Drummond Young took the view that the UK government would be better informed about the desirability of entering into extradition arrangements with another government than the courts $(2016,66)$ However, Lady Paton questioned whether the UK government was, in fact, aware of the conditions prevailing in Taipei prison and that Dean's Convention rights 
were in danger of being breached as a consequence of his planned extradition to Taiwan in October 2013, when the MOU was concluded between the UK and ROC governments $(2016,60)$.

In support of this contention, Lady Paton referred to a letter from the Home Office, dated 22 October 2014, confirming that an expert report had not been commissioned to investigate prison condition in Taiwan prior to the Home Secretary's decision to conclude a MOU with the ROC for Dean's extradition to Taiwan $(2016,10)$. The letter also stated that human rights considerations were a matter for the courts rather than the Home Secretary, as far as decisions about extradition were concerned $(2016,10)$. This is a rather startling assertion. While $\S 87$ of the UK's Extradition Act 2003 makes it plain that the courts are under a duty to ensure that an Applicant's Convention rights are protected in cases of extradition it is beyond doubt that all the organs of a Contracting State are bound by the obligations enshrined in the ECHR. Accordingly, the potential impact of the planned extradition for Dean's Convention rights should have been part of the UK government's assessment of whether to enter into an extradition arrangement with the ROC government. This was not a matter only for the courts. Lady Paton also drew attention to the limited nature of Dr McManus's remit to assess conditions in Taipei prison. His terms of engagement were restricted to an assessment of conditions directly related to the Appellant $(2016,30)$. Further, she alluded to Dr McManus's evidence that, for CPT assessment purposes, it was normal practice for an investigation into conditions in a particular prison to be far more comprehensive and robust in nature. He stated, typically, a team of at least six persons would be involved (including a qualifying medical doctor) and the process would ordinarily take several days in which the whole prison would be assessed and an overnight prison stay would be conducted. Dr McManus conducted a solo inspection 
of Taipei prison over two days. He was not a medical doctor and no overnight inspection was carried out $(2016,30)$.

Lady Clark went as far as to say that this restrictive approach to the investigation of the conditions in Taipei Prison was deliberate $(2016,111)$. During the 2016 hearing, she said that the First Respondent had argued the Appeal Court should only have regard to the conditions in Taipei prison to the extent that they relates directly to the Appellant. However, the majority strongly disagreed with this approach: Lady Clark exclaimed that not only was the Court entitled to have regard to general prison conditions, it was bound to take them into account $(2016,112)$. She pursued the concern regarding access to reliable information about conditions in Taipei prison by expressing the view that the First Respondent could have led evidence to the Court by instructing an expert witness who had direct knowledge and experience of conditions in Taipei prison $(2016,111)$. Lady Clark complained that the absence of such evidence meant the Court had to piece the available evidence together for itself from a range of disparate and limited sources $(2016,111)$. Further, she characterised the efforts to make special arrangements for the Appellant in Taipei prison during the court proceedings as "various sporadic ad hoc proposals and undertakings "(2016, 114). In her view, no-one with any understanding of the requirements of Article 3 in prison settings and knowledge of the system in operation at Taipei prison had thought through a way of creating an Article 3 compliant regime for Dean, assuming this was indeed possible $(2016,114)$.

In the circumstances, it is arguable that the UK government had not taken these extradition arrangements seriously notwithstanding its preparedness to conclude the MOU with the ROC government in the first place. Admittedly, this was a highly unusual case involving the conclusion of an MOU to extradite a single individual who had 
committed a serious crime but one which did not have ramifications for national security. Nevertheless, it is arguable that British officials had not made the arrangements on a due diligence basis. The lack of a thorough initial assessment, by the Home Office, in association with the Foreign Office, regarding the implications of Dean's extradition as far as his Convention rights were concerned, is particularly telling. The unwillingness to commission a full investigation into conditions in Taipei prison, in the context of the present Appeal, strengthens the overall impression that the UK government was not sufficiently engaged in this extradition case. In sharp contrast, in Othman, the UK government had taken considerable measures to ensure that the arrangements made for Othman's extradition were comprehensive, detailed and cogent. For example, the diplomatic assurances contained in the material UK/Jordan MOU provided for the availability of judicial remedies for an extradited person in the event of allegations of mistreatment; ${ }^{97}$ the parties had agreed on the appointment of a credible, independent human rights organisation to monitor compliance with the undertakings which underpinned the extradition arrangements; ${ }^{98}$ and, the UK government had provided substantial funds for the purpose of strengthening the capacity of human rights monitoring in Jordan more generally with a view to bringing about improvements in complying with human rights standards in the requesting State. ${ }^{99}$

Once wider considerations are factored in, such as the fact that the UK and the ROC do not enjoy diplomatic ties and they are not partners for any significant broader purpose, the reasons for the UK government's lack of commitment to the extradition arrangements it had concluded with the ROC become apparent. The UK government

\footnotetext{
${ }^{97}$ The terms of this MOU are set out in Othman, supra note 40, [77].

98 Id. [80-82].

99 Id. [87]; and see Kate Jones, Deportations with Assurances: Addressing Key Criticisms 57 INT'L \&
} COMP. L.Q. 183, 184 (2008). 
was not sufficiently interested in developing its limited, informal relations with the ROC government to devise a strategy designed to address the obvious concerns regarding the arrangements for Dean's extradition to Taiwan. When measured by the extradition arrangements entered into by the UK and Jordanian governments, as tested in the Othman case, the actions of the UK government in relation to Dean's extradition, are clearly inadequate. British officials should have investigated conditions in Taipei prison thoroughly using a knowledgeable and experienced team of experts; they should have devised an Article 3 complaint regime for Dean and made detailed proposals and recommendations concerning the ways in which Dean could access other facilities within Taipei prison well in advance of the court proceedings; they should have ensured that appropriate independent monitoring arrangements were put in place; and a cogent complaints procedure should have been agreed between the parties (including the provision of judicial remedies). Evidently, diplomatic assurances were not sufficient to protect Dean against the prospect of ill-treatment, especially when judged by the actions of the parties to the UK/Jordanian MOU in Othman.

\subsection{The "Community Interests" Argument}

Lord Drummond Young highlighted the pivotal role that extradition arrangements play regarding the proper functioning of criminal justice regimes as they provide the means by which fugitives can be prevented from evading justice. Consequently, he thought that credible requests for extradition should only be refused in exceptional instances $(2016,64)$. Further, he suggested that, as the 2013 MOU constitutes an international agreement concluded between two governments, it should be assumed that diplomatic assurances contained therein would be carried out in good faith $(2016,65 \& 67)$. The recognition of the community interests served by extradition has an established 
pedigree in international law. ${ }^{100}$ In the context of the development of the nonrefoulement principle, it can be traced back to Soering, where the European Court observed that:

"[...] inherent in the whole of the Convention is a search for a fair balance between the demands of the general interest of the community and the requirements of the protection of the individual's fundamental rights. As movement about the world becomes easier and crime takes on a larger international dimension, it is increasingly in the interest of all nations that suspected offenders who flee abroad should be brought to justice. Conversely, the establishment of safe havens for fugitives would not only result in danger for the State obliged to harbour the protected person but also tend to undermine the foundations of extradition. These considerations must also be included among the factors to be taken into account in the interpretation and application of the notions of inhuman and degrading treatment or punishment in extradition cases" $(2016,89) .{ }^{101}$

Nevertheless, it has been acknowledged that Contracting States are not permitted to engage in a balancing exercise when making decisions in extradition cases. Specifically, the Strasbourg Court has made it clear that they cannot weigh the risk that a given individual poses to the national interests of the Contracting State in issue (or to the broader international community) against the harm that he or she is likely to suffer in the event of extradition. ${ }^{102}$ The "risk versus harm" issue was revisited, in $R$

\footnotetext{
100 See Oppenheim, supra note 7, at 950-962.

101 Also see Soering, supra note 39, [110].

102 See Chahal, supra note 54, [81]; and Saadi, supra note 50, [138].
} 
(Wellington) v Secretary of State for the Home Department, where the House of Lords held that the prospect of evading justice could constitute one of a number of factors when determining whether the risk of ill-treatment would satisfy the minimum level of severity of harm required for a breach of Article 3. ${ }^{103}$ However, this approach was overruled by the Strasbourg Court, in Ahmad, where it held that assessments concerning whether treatment satisfies the minimum severity threshold must remain separate from the reasons for seeking extradition. ${ }^{104}$ Accordingly, it is evident that "community interests" cannot influence determinations about whether the Convention rights of the individual in question would be jeopardised in the event of extradition. ${ }^{105}$ In the light of the above, it is clear that Lord Drummond Young's view of the way in which extradition requests should be treated was not consistent with the current Strasbourg jurisprudence on this issue.

\subsection{MOUs, Diplomatic Assurances and International Law}

Lord Drummond Young expressed the view that any doubts concerning Taiwan's international status would increase the chances that the undertakings would be honoured, as the ROC had much to gain by proving that it was prepared to deliver on the extradition arrangements contained in the $2013 \mathrm{MOU}$, and in subsequent undertakings. He sought to harness the authority of international law in this regard by holding that:

\footnotetext{
103 The majority view in Wellington was espoused by Lord Hoffmann, supra note 66, [22-24]. ${ }^{104}$ Ahmad, supra note 55, [172]. In that case, the Court declared that: "Indeed in the 22 years since the Soering judgment, in an art. 3 case the Court has never undertaken an examination of the proportionality of a proposed extradition or other form of removal from a contracting state. To this extent, the Court must be taken to have departed from the approach contemplated at [89] and [110] of the Soering judgment [173]."

105 See R (EM (Eritrea)) v. Secretary of State for the Home Department [2014] 2 WLR 409, [41-43] and [58-64]; and Florea, supra note 81, [32].
} 
"As with any agreement at an international level, an extradition agreement takes effect as a matter of international law. While obviously the enforcement of international law presents much greater difficulties than the equivalent in domestic law, the extent to which a state observes its international obligations or fails to do so can be monitored by diplomatic and consular staff. If it becomes clear that a state is failing to implement its international undertakings, it is likely that other states will be reluctant to conclude agreements with it in future, which is a sanction in itself $(2016,68) . "$

And later:

"The Memorandum of Understanding is an international agreement between states, having force in international law, and the assurances subsequently given by the Taiwanese government are supplemental to that agreement and similarly have force in international law $(2016,81) . "$

The $2013 \mathrm{MOU}$, concluded between the UK and ROC governments, which enabled extradition proceedings to be instituted, via $\S 194$ of the Extradition Act 2003, and which prompted Dean's challenge to the legality of the special arrangements that were put in place with a view to extraditing him to Taiwan, were concerned with the application of UK law. However, as Lord Drummond Young's Opinion shows, the effects this arrangement at the international level must also be considered. 
Although typically governed by treaty arrangements extradition can be effected through other means, including resort to MOUs. ${ }^{106}$ However, it is widely believed that MOUs are not treaties as they do not manifest an intention to create international legal rights and obligations. ${ }^{107}$ Consequently, it has been suggested that these political arrangements are not "governed by international law" in accordance with the definition of a treaty enshrined in the 1969 Vienna Convention on the Law of Treaties. ${ }^{108}$ Nonetheless, Klabbers has argued that MOUs should be interpreted as treaties and the intention that they generate legally binding rights and obligations should be presumed. ${ }^{109}$ Arguably, the popularity of MOUs has troubling ramifications for the normative reach of international law because it creates ambiguity concerning the proper scope of treaty law, ${ }^{110}$ which in certain cases, may only be resolved when a given agreement of arrangement falls to be interpreted by a court or tribunal. ${ }^{111}$ Notwithstanding these significant criticisms, Klabbers has recently changed his position on the legal status of MOUs. He is now prepared to concede that MOUs are not treaties as such. Instead he prefers to draw attention to their "twilight" character (or soft law) while admitting that their use may stem from an intention to generate political obligations, but he claims that their interrelationship with international law

106 Member States of the British Commonwealth effect extradition through the use of MOUs. See the 2002 London Scheme, http://www.oas.org/juridico/english/mesicic3_jam_london.pdf (Last visited Jan.16, 2017).

107 See J. Fawcett, The Legal Character of International Agreements 30 British Yearbook of International Law 381399 (1953); and Anthony Aust, Modern Treaty Law and Practice (2nd ed. CUP 2007), chapter 3.

108 See Aust, id. 20-21. Article 2(1)(a) of the Vienna Convention on the Law of Treaties provides that: "'treaty' means an international agreement concluded between States in written form and governed by international law, whether embodied in a single instrument or in two or more related instruments and whatever its particular designation." 23 May 1969, (1969) 8 I.L.M. 679, (1980) 1155 U.N.T.S. 331.

109 See Jan Klabbers, The Concept of Treaty in International Law (Kluwer Law International 1996), 105118. See Aust, id. 49-52.

110 Aust admits that the growing popularity of MOUs is not without its problems: he notes that "the use of MOUs is now so widespread, some officials may see the MOU as the norm, a treaty being used only when it cannot be avoided". Id. 32.

${ }^{111}$ See, for instance, Maritime Delimitation and Territorial Questions (Jurisdiction) Case (Qatar/Bahrain) (1994) I.C.J. Rep 112. 
remains latent. ${ }^{112}$ In any event, MOUs are particularly useful as a means of entering into arrangements within non-State entities and the ROC has concluded numerous MOUs with a wide range of States that do not recognise it as a de jure State or government. ${ }^{113}$ But while the use of MOUs by States in their dealings with Taiwan has enabled political and commercial relationships to be forged, and strengthened, without direct reference to international law, recourse to such devices hides the legal quality of such arrangements and casts doubt on the influence that international law exerts in such an exceptional context.

Despite the orthodox view that MOUs are not be legally binding per se, it understood that they may have legal consequences, both at the level of international law and in municipal litigation. ${ }^{114}$ As far as Contracting States are concerned, extradition cases invariably involve consideration of the need to discharge certain obligations imposed on the requested State by virtue of the ECHR, including the principle of non-refoulement, under Article 3, and standards concerning fair trial pursuant to Article 6. The legal obligations, imposed by the ECHR, are binding on Contracting States vis-à-vis individuals coming within their jurisdiction, under Article 1 of the Convention, despite the absence of an inter-State character. ${ }^{115}$ Accordingly, it is arguable that the $2013 \mathrm{ROC/UK}$ MOU generated legal effects for the UK government, pursuant to its legal obligations under the ECHR, notwithstanding this MOU's status as a political arrangement. Nevertheless, such obligations would only be satisfied, in Dean v. Lord Advocate, if the UK government (and the UK courts) had conducted rigorous outward-looking assessments of Taiwan's municipal legal system and the integrity of the undertakings given by the ROC government in order to

\footnotetext{
112 See Jan Klabbers, International Law (CUP 2013), 43-45.

113 Aust, supra note 107, 47 and 61.

114 Id. 53-57.

115 The terms of Article 1 of the ECHR are quoted at supra note 96.
} 
establish whether Dean's Convention rights had been breached. In addition, as discussed above, diplomatic assurances do not possess an international legal quality, they too amount to political commitments. However, again, it is arguable that they give rise to legal effects in a similar manner to the way in which MOUs may have legal significance. But, notwithstanding their capacity to generate legal effects, it would be misleading to characterise MOUs and diplomatic assurances as deriving their force from international law per se.

Against this background, Lord Drummond Young seems to have engaged in a somewhat crude assessment of the advantages that may be gained by the ROC government if it complied with the political commitments set out in the $2013 \mathrm{MOU}$, and the subsequent diplomatic assurances (i.e. it may demonstrate to the international community that the ROC is a reliable partner and it could improve bilateral relations in any event). ${ }^{116}$ In his view, the advantages that may accrue to the ROC from honouring the MOU would outweigh the risks of non-compliance. Consequently, in Lord Drummond Young's mind, it was more likely that the ROC would be dependable, as far as Dean's treatment was be concerned. However, the significance of such an assessment for international law (or for the other legal regimes engaged by the case) is unclear and Lord Drummond Young's musings about the likelihood of political compliance are susceptible to the charge of "optimism". ${ }^{117}$ This situation highlights the practical problems, which may arise from the use of non-legal mechanisms, such as MOUs and diplomatic assurances, in general but these normative difficulties are

116 In response to the Edinburgh District Court's favourable first instance decision in Dean $v$ Lord Advocate, the ROC's Ministry of Foreign Affairs issued a press release stating that: "the extradition decision is a fine example of judicial justice being upheld and sets a positive precedent in Taiwan-UK judicial cooperation. In the future, the two sides can use this precedent to further strengthen bilateral cooperation in not only judicial matters, but also other areas of mutual concern. See Press Release Number 124, issued by the Public Diplomacy Coordination Council on 11 June 2014. http://www.mofa.gov.tw/EnMobile/News_Content.aspx?s=67715224F31167E9 (last visited Jan.16, 2017)

117 Lady Clark, 2016 judgment, supra note 1, [116]. 
heightened by the doubts surrounding Taiwan's international legal status. Thus while the 2013 ROC/UK MOU, and the subsequent ROC undertakings, may generate legal effects for the UK, via its own municipal law, and through the ECHR they do not create international legal rights and obligations of an at the level of general international law. As a result, it is unclear how the key (non-legal) devices - the $2013 \mathrm{MOU}$ and the subsequent diplomatic assurances - have legal effect as far as the ROC in Taiwan is concerned: their reliability is open to question from the perspective of general international law. ${ }^{118}$

\section{Conclusion}

The two judgments delivered by the Scottish Court of Appeal in the case of Dean v. Lord Advocate offer a series of fascinating insights into the interpretation and interaction of municipal law, the jurisprudence of the European Convention on Human Rights and international law in a difficult setting. Despite the finding that the ROC qualified as a "territory" pursuant to the application of $\S 194$ of the 2003 Act, in its 2015 judgment, in the 2016 Judgment the majority doubted the practical significance of the ROC's diplomatic assurances in the light of the general conditions prevailing in Taipei prison. In reaching its decision, the majority seemed to be determined to apply Convention standards to Taipei prison and it was not swayed by the relativist interpretation favoured by Lord Drummond Young in his dissenting Opinion. Further, the UK government's approach to the task of satisfying the requirements of Article 3 in the context of Dean's planned incarceration in Taipei prison was inadequate. It did not engage fully with the ROC government, and its prison authorities, on this issue,

\footnotetext{
118 One way in which political agreements and understandings can have effect in international law is via the principle of estoppel. See Chagos Marine Protected Area Arbitration (Mauritius v. United Kingdom) Award (18 March 2015). However, estoppel clearly has no application to the present situation.
} 
especially when compared with the way that the UK government worked with the Jordanian government (and human rights organisations) in the Othman case to produce a meaningful arrangement that sought to protect the rights of any affected individuals.

The 2013 ROC/UK MOU and the prospect of Dean's extradition, following the Appeal Court's 2015 decision, were widely viewed in Taiwan as signs of the ROC's developing relations with the international community. However, in the 2016 judgment, concerns about Taiwan's political isolation from the international community reasserted themselves. In particular, the majority were troubled by the lack of independent monitoring of Dean's treatment as a means of ensuring that the ROC's diplomatic assurances were upheld and the absence of international monitoring of prison conditions in Taiwan given the limited protection that could be provided by British officials stationed in Taipei. It might be tempting to see the outcome in the case of Dean v. Lord Advocate in negative terms. However, by initiating the extradition arrangements with the UK government, via the $2013 \mathrm{MOU}$, the ROC government prevented Dean from evading justice: he was kept in custody in a Scottish prison for the duration of the present court proceedings. As Lady Paton noted, Dean actually spent longer in prison than he would have done if he had received a four-year sentence for a crime committed within the UK's jurisdiction $(2016,60)$. This outcome shows that the community impulses underpinning extradition remain strong notwithstanding the need for Contracting States to ensure that extradition arrangements comply with the ECHR's provisions. Moreover, despite the significant concerns about the character of MOUs and diplomatic assurances from the perspective of international law, the fact that doubts about Taiwan's international legal status did not stop the conclusion of the 2013 extradition arrangement, supports the existence of an inclusive conception of 
community interests and a rudimentary commitment to the (international) rule of law even though those extradition arrangements were imperfectly realised in the present case. 